\title{
ORGANIZATION AND EXPERIENCES OF A CARDIAC RESUSCITATION SERVICE*
}

\author{
Max MinucK, M.D. $†$
}

THE RECENT INTRODUCTION of relatively simple but effective techniques for artificial ventilation, artificial circulation, and external defibrillation has made it possible to develop hospital programmes designed to bring trained personnel and equipment rapidly to the patient with cardiac arrest. It has become apparent that thousands of hospital patients who die from acute cardiac failure, may be resuscitated without serious neurological sequelae provided that these rescue techniques can be started within the first four minutes following death. Many hospitals have instituted resuscitation services and several have described their experiences. ${ }^{1-0}$ There is a wide range in the published survival rates. The reports that group cardiac arrests occurring outside the operating room with arrests occurring in the operating suite have a relatively high survival rate. ${ }^{1,2}$ On the other hand, the results are often disappointing when the reports deal only with patients suffering arrest outside the operating suite ${ }^{4,6}$-the so-called "medical" arrests. Low survival rates can be improved with knowledge gained by experience, as has been demonstrated by Minogue and his co-workers. ${ }^{7}$

This paper describes the organization of the resuscitation service at the St. Boniface General Hospital and presents an analysis of its initial experiences.

Early in 1963 the Manitoba Hospital Commission, recognizing the necessity for hospital administrations to assume responsibility for treating cardiac arrest occurring in hospital patients, asked the minister of health to study this problem. The minister in turn formed a committee consisting of medical representatives from each hospital in Metropolitan Winnipeg, under the chairmanship of Dr. T. E. Cuddy. The committee's report emphasized the need and importance for establishing such a hospital service. Further, it was the opinion of the committee that since the anaesthetist possesses the skill and knowledge required for cardiac and respiratory resuscitation and is already directly concerned with the maintenance of circulation and respiration in the operating room, he was the most suitable person to head such a service. ${ }^{8}$

Coincidentally, a letter was written by the author to the hospital administrator asking him to institute a "Cardiac Resuscitation Service." The governing board of the St. Boniface General Hospital recognized the merits of this request and rapidly agreed to help us to develop such a service.

The basic requirements for the organization of an efficient resuscitation service are departmental organization, centralization of quarters, adequate equipment and its surveillance, and a programme of education. From the beginning it was

\footnotetext{
'Presented at the Annual Meeting of the Canadian Anaesthetists' Society at Charlottetown on June 25, 1965.

†Director, Department of Anaesthesia, and Chairman of the Resuscitation Service, St. Boniface General Hospital, St. Boniface, Manitoba.
} 
realized that it would be a laborious and time-consuming undertaking to carry out the functions and duties of such a committee on a long-term basis, and in addition it was obvious that the interest of many disciplines would be required. With this in mind, the committee was enlarged, and at the present time is made up of a chairman and representatives from departments of anaesthesia, cardiology, respirology, surgery and paediatrics. The committee meets on call of the chairman to discuss problems that have arisen and any suggestions for changes in the resuscitation routine.

Table I contains a list of the responsibilities of the cardiac resuscitation committee. All the members participate in the numerous lectures and demonstrations that are given throughout the year to the interns, registered nurses, licensed practical nurses, ward aides, and orderlies. We emphasize to them that ultimate success is possible only if the personnel "on the spot" institute the ABC (Airway, Breathing, Circulation) immediately upon diagnosing the arrest. Full use is made of "Resusci-Ann" for demonstration and practice of the proper techniques for establishing an airway and performing artificial breathing and circulation. An attempt is made to impress upon those attending the lectures that many patients enter the hospital in the terminal stage of their illness, and neither the patient nor the members of the family should be subjected to the mental agonies of fruitless attempts at resuscitation; these patients have a right to a dignified death.

TABLE I

The Responsibilities of the Resuscitation Commitee

\footnotetext{
Clinical

1. To ADVISE on the equipment contained in:

(a) the emergency baskets (on the ward)

(b) the resuscitation cart (in post-surgery)

2. To MAINTAIN SURVEILLANCE of the contents of the baskets

3. TO RESPOND to the code call " 99 "
}

Educational. Continuing education of all hospital personnel is essential. This is done by means of lectures and demonstrations to the following groups.

1. Ward personnel:

registered nurses, orderlies, licensed practical nurses (limited to airway, breathing, and circulation)

2. Interns and residents (complete management,

3. Physicians (complete management)

Research and Study

1. To sTUDY records of all cases in order to review methods

2. To MaINTAIN a library of pertinent material

3. TO TEST new drugs and techniques clinically and in the laboratory.

At the present time the equipment required for resuscitation is divided into two main groups. An emergency basket is kept on each ward and contains the items illustrated in Figure 1 and listed in Table II.

The location of this emergency basket is known to all ward personnel and is brought to the room as soon as a patient is found in "arrest." Each member of the committee has several wards assigned to him and at random intervals is asked to inspect the emergency baskets to determine if all the equipment is present and 


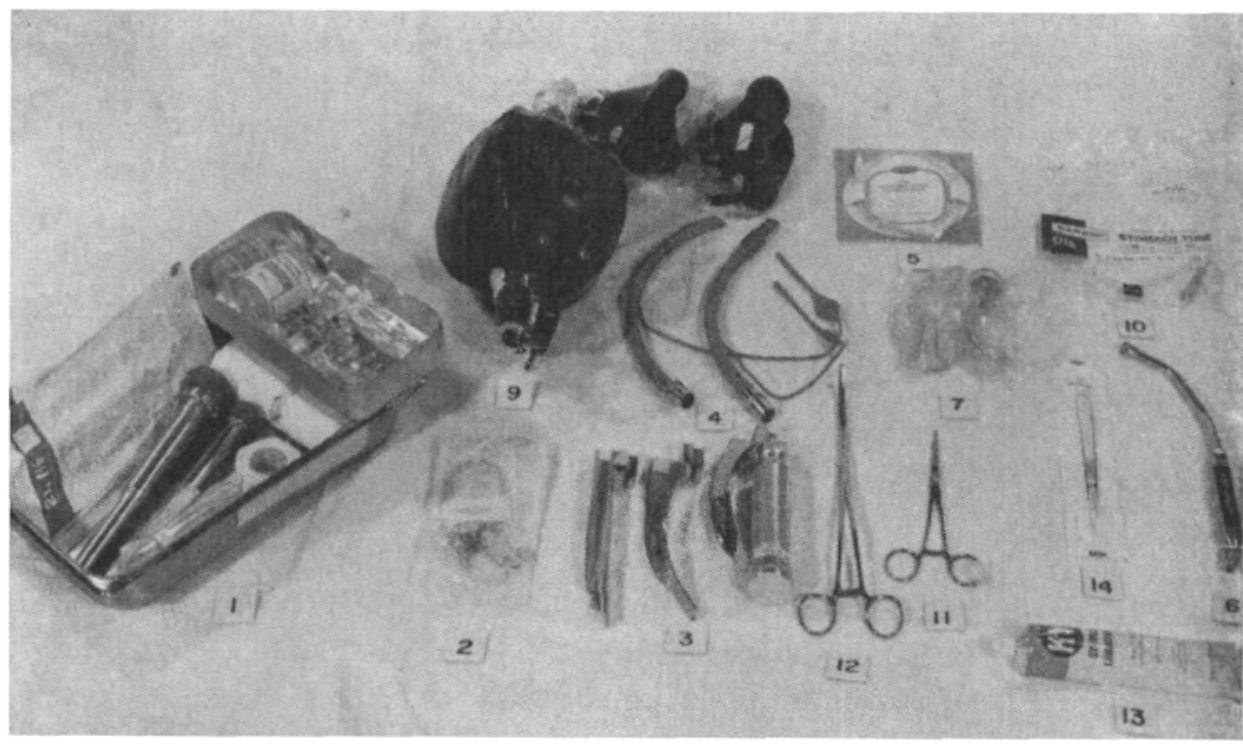

Fraure 1. Equipment kept in the emergency basket on every ward. The numbers refer to Table II. The coil of rubber tubing is missing from the picture.

TABLE II

\section{Contents of the Emergency Basket}

1. A small stainless steel container containing:

(A) Drugs (two of each)

$\begin{array}{ll}\text { Calcium chloride } & 1 \mathrm{gm} . \text { in } 10 \mathrm{ml} . \\ \text { Adrenaline } & 1 \mathrm{mg} . \text { in } 1 \mathrm{ml} . \\ \text { Atropine } & 1 / 100 \mathrm{gm} \text {. in } 1 \mathrm{ml} . \\ \text { Xylocaine } & 20 \mathrm{mg} . / \mathrm{ml} . \\ \text { Isuprel } & 1 \mathrm{mg} . / 5 \mathrm{ml} .\end{array}$

3-5 ml. intracardiac

dilute to $10 \mathrm{ml}$., 3-5 $\mathrm{ml}$. intracardiac intravenously

$100 \mathrm{mg}$. intracardiac

Water for injection

(B) A range of needles from size 18 to 22 (B-D disposable short-bevelled) Spinal needles

Rochester or Buffalo needles

(C) Syringes: $2 \mathrm{ml}$., $5 \mathrm{ml}$., $10 \mathrm{ml}$., and $20 \mathrm{ml}$.

(D) Roll of 1 in. tape

2. Three-way stopcock

3. Laryngoscope with blades

4. Cuffed endotracheal tubes with connectors to fit

5. Plastic suction catheters

6. Metal suction tip

7. Pharnygeal airways

8. Rubber tubing

9. "AMBU" self-inflating bag and mask

10. Gastric tube, size 18

11. Halstead forcep

12. Dressing forcep

13. Lubafax

14. Scalpel with a no. 11 blade

in working order. He reports his findings to a central office (Anaesthetic Department). The heavier equipment is kept on the "resuscitation cart" which is stored in post-surgery and reserved exclusively for cardiac resuscitation. The contents of this cart are listed in Table III. Figure 2 is a view of the cart taken from the front. 
TABLE III

Contents of the Emergency Cart
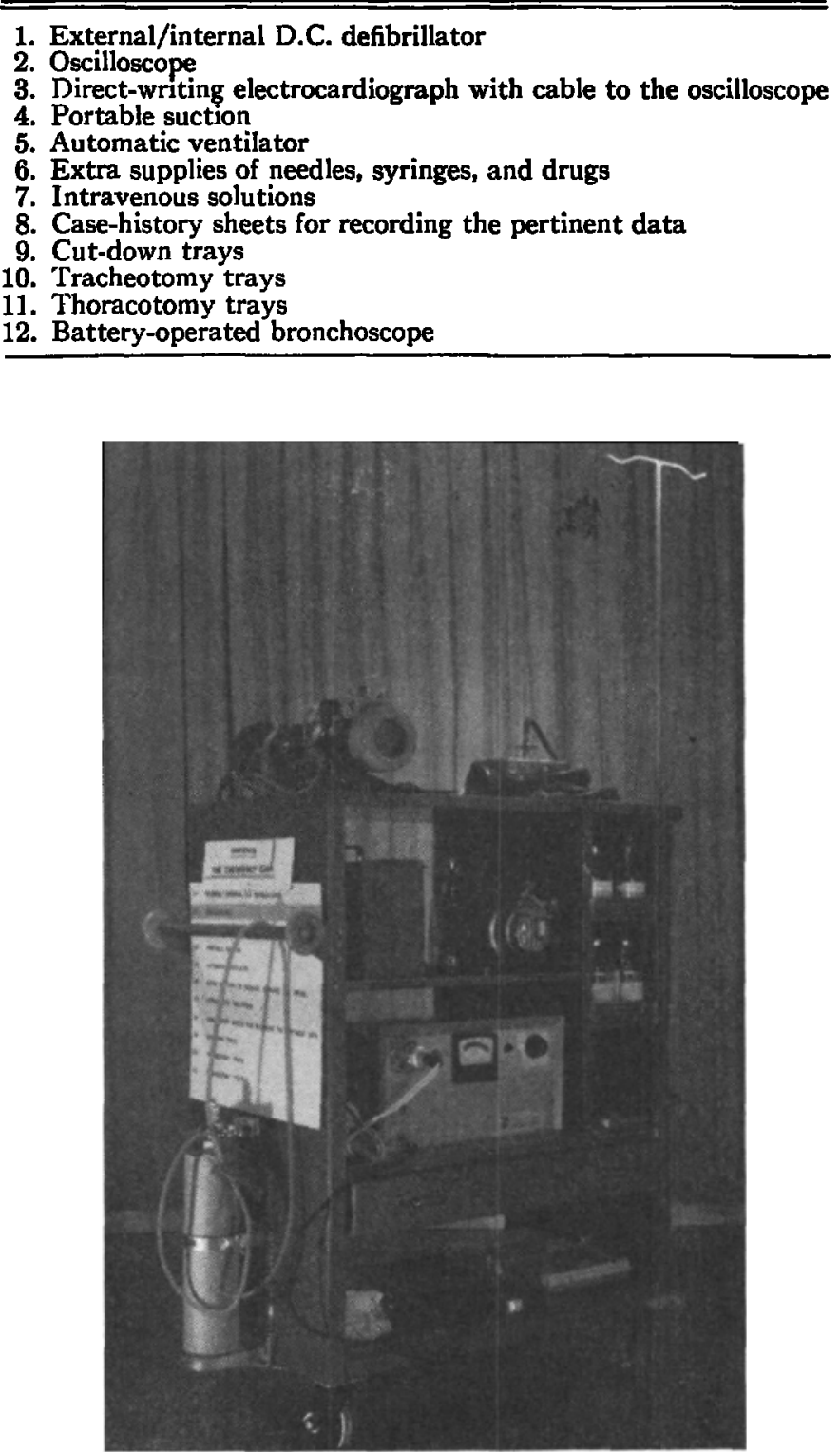

Figure 2. A front view of the resuscitation cart.

Figure 3 represents the plan of action in current use at the St. Boniface General Hospital, and the following is a tabulation of the step-by-step plan of action that is followed when resuscitation is required.

1. A nurse or any other person who discovers the patient in "arrest" starts the initial steps and directs someone to notify the telephone operator that the emergency exists. 


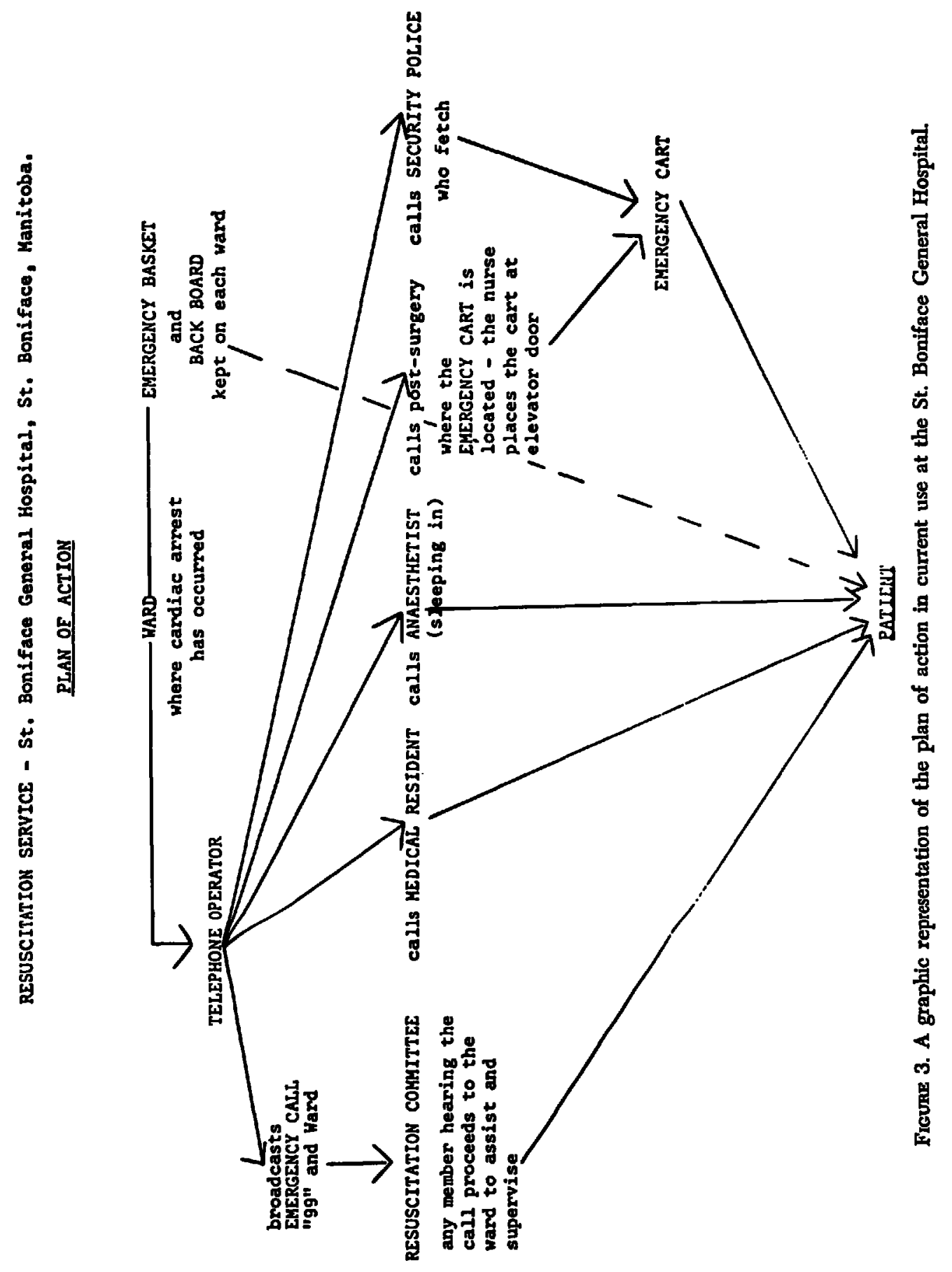


2. The telephone operator issues a call " 99 " followed by the number of the ward, and she contacts: (a) the medical resident on call, (b) the anaesthetist on call, (c) post-surgery, (d) the security police between the hours of 8 A.M. and 9 P.M.

3. The resident and anaesthetist proceed to the ward.

4. Post-surgery delivers the resuscitation cart to the service elevator and, between 9 P.M. and 8 A.M. (when the security police are not on duty) takes the cart to the ward.

5. Between 8 A.M. and 9 P.M. the security police on duty take charge of an elevator, pick up the cart on the second floor, and deliver it to the ward.

6. After completion of the resuscitation attempt, whether successful or not, a special resuscitation form is filled out by the anaesthetist or the member of the resuscitation committee who is present, and returned to the anaesthetic office.

7. The surviving patient is now moved to an intensive care unit where he is monitored for a minimum period of 72 hours.

\section{Material}

For the committee's purpose, "cardiac arrest" is defined as a sudden and unexpected cessation of circulation. The diagnosis and management of cardiac arrest has been previously described ${ }^{9,10}$ and will not be discussed here. The cardiac arrests forming the basis of this report occurred on the wards, in intensive care areas, or in the emergency ward. Sixty-three patients were treated by the resuscitation service during the nineteen months from September 1, 1963, to March 31, 1965. There were 29 females and 34 males. The youngest was 17 and the oldest 86. The age distribution is shown in Table IV.

TABLE IV

Age Distribution

\begin{tabular}{lc}
\hline \hline Age (years) & Frequency \\
\hline Under 20 & 3 \\
$21-29$ & 1 \\
$30-39$ & 0 \\
$40-49$ & 12 \\
$50-59$ & 10 \\
$60-69$ & 19 \\
$70-79$ & 12 \\
$80-89$ & 6 \\
Total & 63 \\
\hline
\end{tabular}

Table $\mathrm{V}$ lists the causes of the arrest, the number of immediate survivors and the ultimate survivors in each group.

Two-thirds of the patients treated by the resuscitation service had suffered arrest following acute myocardial infarctions or some other cause for acute cardiac collapse ( 42 cases). Many patients died from diseases that were incompatible with continuing life, and efforts at resuscitation were abandoned as soon as this became known. 
TABLE V

Cases Classified as to Causes of Arrest, Number of Immediate Successes, and Ultimate SURVIVORS

\begin{tabular}{|c|c|c|c|}
\hline Cause of arrest & Number & $\begin{array}{l}\text { Immediate } \\
\text { survivors }\end{array}$ & $\begin{array}{l}\text { Ultimate } \\
\text { survivors }\end{array}$ \\
\hline $\begin{array}{l}\text { Myocardial infarction } \\
\text { Myocardial failure with or without acute pulmonary oedema } \\
\text { Myocardial failure due to valvular disease } \\
\text { Severe pulmonary disease } \\
\text { Aspiration of gastric contents } \\
\text { Massive pulmonary embolus } \\
\text { Asphyxia } \\
\text { Cerebro-vascular accident } \\
\text { Uremia } \\
\text { Bacterial shock } \\
\text { Hemorrhage } \\
\text { Barbiturate intoxication } \\
\text { Unknown }\end{array}$ & $\begin{array}{r}31 \\
9 \\
2 \\
3 \\
3 \\
2 \\
1 \\
3 \\
2 \\
3 \\
2 \\
1 \\
1\end{array}$ & $\begin{array}{r}14 \\
2 \\
1 \\
2 \\
0 \\
1 \\
0 \\
1 \\
0 \\
3 \\
0 \\
1 \\
0\end{array}$ & $\begin{array}{l}\mathbf{5} \\
\mathbf{0} \\
0 \\
0 \\
\mathbf{0} \\
\mathbf{0} \\
\mathbf{0} \\
\mathbf{0} \\
0 \\
\mathbf{0} \\
\mathbf{0} \\
\mathbf{0} \\
\mathbf{0}\end{array}$ \\
\hline Total & 63 & 25 & $\mathbf{5}$ \\
\hline
\end{tabular}

The rescue was considered to be successful if the patient became conscious and aware of his surroundings and breathed spontaneously, or alternatively, if he was able to maintain an adequate blood pressure for at least one to two hours. Twenty-five patients or 39.7 per cent met these criteria, but only five recovered permanently and were discharged without any neurological defects. These patients were well enough to be able to resume their normal activities, which ranged from plumber's assistant to bank manager. One patient was readmitted to the hospital four months following discharge, having had another myocardial infarction, and he died shortly after admission.

The complications that followed external cardiac compression are listed in Table VI.

TABLE VI

Complications Following External Cardiac Massage

\begin{tabular}{lc}
\hline \multicolumn{1}{c}{ Complication } & Number \\
\hline Fractured ribs (bilateral and less than 4) & 4 \\
Fractured ribs (bilateral and more than 4) & 6 \\
Pneumothorax associated with fractured ribs & 3 \\
Fractured sternum & 1 \\
Bone-marrow embolism associated with fractured ribs & 3 \\
Lacerated liver & 2 \\
Lacerated spleen & 1 \\
None & 20 \\
\hline
\end{tabular}

Autopsies were done in 40 cases, or 69 per cent of the deaths. Twenty patients did not suffer any injuries attributable to the resuscitative efforts. Sixteen patients sustained multiple rib fractures and one a fractured sternum. Three patients demonstrated bone marrow embolism associated with the rib fractures, three others with fractured ribs developed a pneumothorax-these were recognized and treated. Two patients had lacerated livers and one a lacerated spleen. All the 
lacerations were slight and did not contribute to the deaths. No serious trauma was seen as a result of direct intracardiac injections except for an occasional small myocardial petechia.

\section{Discussion}

The recent development of resuscitative techniques which can be used efficiently by non-medical hospital personnel has led to the organization of hospital cardiac resuscitation services in many centres. Only a few reports have appeared in the literature, and it was felt that a description of our programme and initial experiences might be useful to other hospitals seeking to develop their own resuscitation programmes.

Since our resuscitation service treated only "medical" cardiac arrests, the basic underlying disease was serious and it was inevitable that the number of survivors would be small; but the rescuers were successful in restoring an adequate, though temporary, circulation in almost 40 per cent of those treated.

It is of interest to note that none of the patients whose hearts arrested in asystole were permanent survivors, although 13 of the 41 could be listed as temporary successes. All the survivors demonstrated ventricular fibrillation associated with massive myocardial infarcts. This is similar to the experience reported by Minogue and his co-workers. ${ }^{7}$ In his series, in nine long-term survivors of patients with myocardial infarctions only one showed asystole.

The record of 5 survivors in 31 cases of massive myocardial infarction is indeed heartening. The number might have been larger but for 2 unfortunate accidents that are worthwhile to relate. One patient had been successfully defibrillated following myocardial infarction-she awoke alert and oriented to her surroundings, the pulse was strong and regular, and her blood pressure was maintained at a reasonable level without the need for vasopressors. Ventricular fibrillation recurred nine hours later and this time we were unable to defibrillate the heart, in spite of many attempts. It was discovered later that the wiring of the electrode plate was defective and none of the electrical energy passed through the patient. A second patient was resuscitated following a severe infarction. Several hours later the oscilloscope revealed a complete A-V dissociation with a slow ventricular rate. Since he was extremely restless he required some light anaesthesia with sodium thiopentone and nitrous oxide and oxygen to permit the placing of an internal pacemaker electrode. While recovering from the anaesthetic he vomited and inhaled gastric contents. He died several hours later as a result of this accident.

Evidence has accumulated to reinforce our impression that constant monitoring of coronary patients in a special unit will reduce mortality from this disease. ${ }^{11}$ Should a cardiac arrest occur in the special ward, it will be detected immediately and resuscitative measures can be instituted "on the spot" by trained personnel. This will result in the salvage of a significant number of people. For example, 210 patients with acute myocardial infarctions were admitted to the St. Boniface General Hospital during 1963. Fifty-three of these patients, or 25.1 per cent, died. If this figure could be reduced to the 15.2 per cent attained by Day ${ }^{12}$ in his intensive coronary care area this would represent the salvage of 20 patients. 
The responsibilities of a resuscitation service include the clinical and laboratory investigation of drugs and techniques used for cardiac resuscitation. With this in view, prospective studies are being planned for the future.

\section{SUMMARY}

The incidence of cardiac arrest occurring in hospital patients away from the operating room or other locations where anaesthetic procedures are carried out is impossible to estimate. Of the patients who suddenly and unexpectedly develop a cardiac arrest, only a few survive. The survival rate is low, for most patients die from their underlying disease. But many are salvageable.

The organization and development of resuscitation services in the hospital is an endeavour towards improving techniques and methods so that cardiac arrest may be successfully treated. No success can be possible without the wholehearted support of the administration, the nurses and their supervisors, and especially the members of the Resuscitation Committee. As far as the St. Boniface General Hospital is concerned this essential co-operation has been conspicuous.

Table VII summarizes our experience: a total of 63 patients were treated. Twenty-five were temporarily resuscitated and five recovered sufficiently to return home and assume their normal activities. It is felt that even this small number of rescues justified the expense and the tremendous outlay of effort by a large number of interested people, and it is anticipated that the survival rate will climb with continued experience."

TABLE VII

SUMMARY OF EXPERIENCES

\begin{tabular}{lccc}
\hline \hline Initial cardiac rhythm & Number & $\begin{array}{c}\text { Immediate } \\
\text { success }\end{array}$ & $\begin{array}{r}\text { Ultimate } \\
\text { survivors }\end{array}$ \\
\hline Ventricular fibrillation & 22 & 12 & 5 \\
Asystole & 41 & 13 & 0 \\
Total & 63 & 25 & 5 \\
\hline
\end{tabular}

\section{RÉSUMÉ}

Il est impossible d'estimer la fréquence de l'arrêt cardiaque qui survient dans l'hôpital chez des malades qui sont loin de la salle d'opération ou dans d'autres endroits où il se pratique de l'anesthésie. Parmi les malades qui présentent un arrêt cardiaque soudainement, de façon inattendue, seulement quelques-uns survivent. Le taux de survivance est bas; la plupart meurent de maladies sousjacentes mais plusieurs sont récupérables.

L'organisation et l'expansion des services de ressuscitation dans un hôpital constituent un effort en vue de l'amélioration des techniques et des méthodes

\footnotetext{
- Since the completion of this report we have successfully resuscitated three further patients. All patients were males in their $5^{\circ}$ 's, and their hearts had stopped in ventricular fibrillation following acute myocardial infarctions.
} 
pour que l'arrêt cardiaque puisse être traité avec succès. On ne peut obtenir de succès sans le support généreux de l'administration, des garde-malades et des surveillants et spécialement des membres du "Comité de ressuscitation".

En ce qui concerne l'hôpital Général de St-Boniface, cette coopération essentielle a été simplement remarquable.

Le Tableau VII résume nos expériences - un total de 63 malades furent traités. Vingt-cinq ont été ressuscités temporairement et cinq d'entre eux devinrent assez bien pour rentrer d la maison et reprendre leurs activités. Nous avons la conviction que même ce petit nombre de récupérés justifie les dépenses et l'immense effort accompli par un grand nombre de personnes intéressées, et nous anticipons que le taux de survivance va s'accroître si nous continuons l'expérience.

\section{ACKNOWLEDGMENTS}

I wish to acknowledge the co-operation of the following physicians who are members of the Resuscitation Committee: Drs. J. Barwinsky, R. S. Lambie, J. MacLean, D. Mymin, D. Snidal, and K. Wylie. Mrs. K. DeJong and Mrs. R. Beeman, who organized the lectures and demonstrations given to all the nonphysician personnel, deserve our sincere gratitude.

\section{REFERENCES}

1. Srres, H. K. \& Ammen, N. Emergency Treatment of Cardiac Arrest. Lancet. 2: 46 ( 1963 ).

2. Jude, J. R.; Koewenhoven, W. B.; \& KnICKsarbockern, G. C. Clinical and Experimental Application of a New Treatment for Cardiac Arrest. S. Forum. 11: 252 (1960).

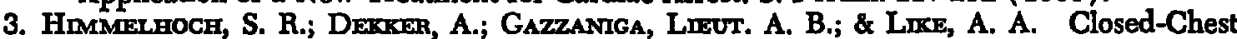
Cardiac Resuscitation. New England J. Med. 270: 118 (1964).

4. Brown, K. W. G.; MacMmitun, R. L.; Forbati, N.; Mer'Grano, F.; \& Scott, J. W. Coronary Unit: An Intensive-Care Centre for Acute Myocardial Infarction. Lancet. 2: 349 (1963).

5. Pontax, R. W.; Robnson, B. F.; \& Leatham, A. G. Notes on Cardiac Resuscitation Including External Cardiac Massage. Brit. Med. J. 1: 636 (1963).

6. Klassen, G. A.; Broadhurst, C.; Peretz, D. I.; \& Jornson, A. L. Cardiac Resuscitation in 126 Medical Patients. Lancet. 1: 1290 (1963).

7. Mnnogue, W. F.; Smossant, A. A.; \& Grace, W. J. External Cardiac Massage for Cardiac Arrest Due to Myocardial Infarction. The Am. J. Card. 13: 25 (1964).

8. Report of a Study Group on Cardiac Resuscitation in the General Hospitals of Metropolitan Winnipeg. Man. Med. Rev. 44 : 259 (1964).

9. Mnvuck, M. Management of Cardiac Arrest. Canad. M.A.J. 88 : 152 (1963).

10. - The Chemotherapy of Cardiac Arrest. Canad. M.A.J. 92: 16 (1965).

11. Yu, P. N.; Fox, S. M.; IMBODEN, C. A., JR.; \& KILIIP, T. III. Coronary Care Unit (1). Mod. Concepts Cardiovas.Dis. 34 (1965).

12. DaY, H. G. An Intensive Coronary Care Area. Dis. Chest. $44: 423$ (1963). 